Article

\title{
Chemical Composition and Hazardous Effects of Leachate from the Active Municipal Solid Waste Landfill Surrounded by Farmlands
}

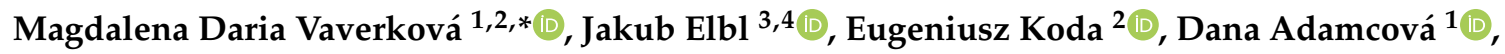 \\ Ayla Bilgin ${ }^{5}{ }^{\circ}$, Vojtěch Lukas ${ }^{3}{ }^{(0}$, Anna Podlasek ${ }^{2}{ }^{\circledR}$, Antonín Kintl ${ }^{4}$, Małgorzata Wdowska ${ }^{2}$, \\ Martin Brtnický ${ }^{6,7}$ and Jan Zloch ${ }^{1}$ \\ 1 Department of Applied and Landscape Ecology, Faculty of AgriSciences, Mendel University in Brno, \\ Zemědělská 1, 61300 Brno, Czech Republic; dana.adamcova@mendelu.cz (D.A.); jan.zloch@mendelu.cz (J.Z.) \\ 2 Institute of Civil Engineering, Warsaw University of Life Sciences-SGGW, Nowoursynowska 159, \\ 02776 Warsaw, Poland; eugeniusz_koda@sggw.edu.pl (E.K.); anna_podlasek@sggw.edu.pl (A.P.); \\ malgorzata_wdowska@sggw.edu.pl (M.W.) \\ 3 Department of Agrosystems and Bioclimatology, Faculty of AgriSciences, Mendel University in Brno, \\ Zemědělská 1, 61300 Brno, Czech Republic; jakub.elbl@mendelu.cz (J.E.); vojtech.lukas@mendelu.cz (V.L.) \\ 4 Agricultural Research, Ltd., Zahradní 1, 66441 Troubsko, Czech Republic; kintl@vupt.cz \\ 5 Faculty of Engineering, Artvin Coruh University, Seyitler Campus, 08000 Artvin, Turkey; \\ ayla.bilgin@artvin.edu.tr \\ 6 Department of Agrochemistry, Soil Science, Microbiology and Plant Nutrition, Faculty of AgriSciences, \\ Mendel University in Brno, Zemědělská 1, 61300 Brno, Czech Republic; martin.brtnicky@mendelu.cz \\ 7 Institute of Chemistry and Technology of Environmental Protection, Faculty of Chemistry, Brno University \\ of Technology, Purkynova 118, 62100 Brno, Czech Republic \\ * Correspondence: magda.vaverkova@uake.cz
}

Received: 24 March 2020; Accepted: 1 June 2020; Published: 2 June 2020

\begin{abstract}
Landfill leachates are potentially harmful to the environment and to human health. The objective of this study was to characterize leachates in order to analyze whether a relationship exists between the stored waste and the composition of leachates, and to detect possible leakages of pollutants into the environment. To achieve these objectives, field data, Global Positioning System data and physico-chemical data were used. Biological tests are becoming increasingly popular in determining leachate toxicity; therefore, two toxicity tests were performed with the seeds of white mustard (Sinapis alba L.) and duckweed (Lemna minor L.). Leachates were sampled from the leachate pond. Groundwater quality was monitored by using drill holes. The research and analysis carried out are important to determine their potential impact on agricultural areas located near the landfill. Demonstrably increased $(\mathrm{P}<0.05)$ concentrations of heavy metals were detected only in the leachate pond which closes the landfill body, where it links up with the landfill insulation layer. Water sampled from drill holes reaching into groundwater was not contaminated. The results showed that the leachates did not leak outside the landfill. Nevertheless, they were found to be phytotoxic. Both toxicity tests showed that the increasing amount of leachates resulted in the increasing growth inhibition of the tested plants. The proper handling of leachates should have been ensured.
\end{abstract}

Keywords: landfill; solid wastes; leachates; toxicity; heavy metals; absorbable organic halogens (AOX)

\section{Introduction}

Recently, the amount of waste, particularly municipal solid waste (MSW), has been rapidly growing in many countries worldwide due to the increasing standard of living or because of industrial 
and business development [1-3]. One of the most widespread methods used for the final disposal of MSW is landfilling [1]. The global trend in landfilling applies not only to big industrial cities with thousands of tons of waste disposed on landfills every day [3,4], but also to rural areas where similar amounts of waste are landfilled each year.

MSW disposed in landfills is subject to chemical, physical and biological reactions and transformations during which nutrients, elements and gases are released $[5,6]$. These come into contact with water and create a leachate. They contain biologically degradable and non-degradable organic compounds, humic substances, ammonia nitrogen $(\mathrm{N})$, heavy metals (HMs) and chlorinated salts [7]. Sanitary landfill is insulated from the soil by impermeable sealing layer (clay or foil) [6,7]; however, water can enter it in the form of precipitation or can be released from the stored waste. The composition of leachates and their impact on the environment, vegetation and human health have raised concerns, and there are numerous studies currently dealing with the issue [7-13]. The amount of leachates and their quality are monitored at regular intervals directly in the landfill at the inlet into the insulated leachate pond. The amount of leachates is affected by total rainfall in the research location. In months with frequent occurrences of torrential rains, the amount of leachates increases and the pollutants are diluted. On the other hand, the leachates become more concentrated in dry periods. The analyses of leachate toxicity demonstrate the potential harmfulness of leachates to the environment, and this is why they have to be disposed in accordance with the applicable legislation [14]. Landfills may fail and contaminate the groundwater used by crops in the adjacent agricultural area and on the landfill surface [14-16]. Though the impact of landfills on ecosystems is defined by means of physico-chemical analyses of leachates and groundwater, their toxicity can hardly be predicted because of their specific composition. It follows that toxicological research focused on the synergic effects of pollutants contained in leachates is necessary [17]. Since the leachates from MSW landfills are characterized by various compositions, biological tests are becoming more popular in determining their toxicity [12-14,18]. A test of leachate toxicity for higher plants was carried out by Zloch et al. [14,18]. According to that research, Sinapis alba L. is ideal for studying the leachate toxicity because it is sensitive to a range of chemicals [14,18]. Kalčíková et al. [19] consider that Sinapis alba L. belongs to sensitive species and is often used to test toxicity. Moreover, research conducted by Mackenzie et al. [20] and Marchand et al. [21] proved that Lemna minor L. was effective in assessing leachate toxicity.

Therefore, the current authors hypothesized that the use of physical and chemical indicators (obligatory in landfill monitoring) and phytotoxicity tests would enable the determination of a potential impact of the MSW landfill on the adjacent environment. The phytotoxicity of landfill leachates was assessed using Sinapis alba L. and Lemna minor L. as bioindicators of leachate toxicity. The objectives of this study were to: (a) characterize the MSW landfill leachate; (b) analyze whether a relationship exists between the stored waste and the composition of leachates; (c) detect possible leakages of pollutants from the landfill body into the groundwater and further into the environment; and (d) determine the toxicity of leachates. To achieve these objectives, field data, GPS data, physico-chemical data and phytotoxicity tests were used to assess the pollution by leachates.

\section{Materials and Methods}

\subsection{Landfill Site Characterization}

The MSW landfill in Zdounky (N49 ${ }^{\circ} 13.66253^{\prime}$, E17 $\left.19.13927^{\prime}\right)$, which is operated by the company DEPOZ Ltd. residing in Zdounky 27 (Figure 1), receives more than $10 \mathrm{Mg}$ of waste daily, and its total capacity is over $25,000 \mathrm{Mg}$. The waste comes from agricultural production, gardening, forestry, game management, fisheries (waste plastic materials), waste from fruit processing, textile industry waste, waste from power plants and other combustion facilities, waste from the production of earthenware and bricks, packaging, concrete, bricks, roof tiles, earth, asphalt mixtures, and waste from wastewater treatment plants, etc. The total landfill area is $69,500 \mathrm{~m}^{2}$, the total volume of deposited waste is $992,800 \mathrm{~m}^{3}$ and the total amount of deposited waste is $1,280,750 \mathrm{Mg}$. 


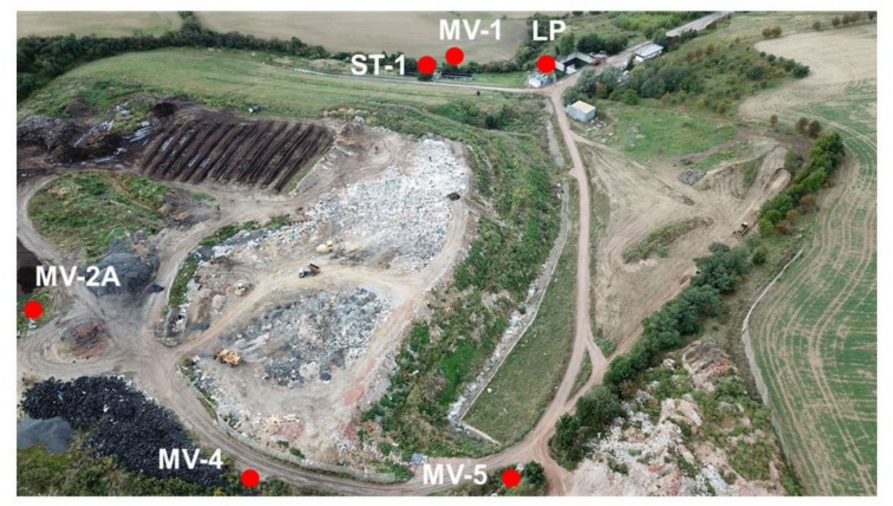

Figure 1. Landfill location and placement of individual monitoring objects (water sampling points). MSW, municipal solid waste.

The landfill site (Figure 2) can be divided into four basic sectors: (1) the sector ready for reclamation; (2) the composting plant; (3) the closed sector; and (4) the landfill facilities. Leachates are displaced through recirculation (sprayed) onto the landfill surface. Measures are adopted to reduce dustiness on the landfill body and in its vicinity by sprinkling the road and by the recirculation of leachates onto the landfill body, by consistent waste compaction and by covering inactive parts of the body with inert material.

\subsection{Monitoring of Groundwater and Leachates}

The potential impact of landfill on the environment was studied from 2008-2013 through the long-term groundwater quality monitoring in the nearest vicinity of the landfill. The drill holes used in the research (Figure 1 and Table 1) were as follows: MV-1 (drill hole) under the landfill front; MV-2A (drill hole) landfill edge; MV-4 (drill hole) upper landfill edge; MV-5 (drill hole) upper landfill edge; ST-1 (shaft ring well) under the landfill front; and LP (leachate pond) western landfill edge. Hazardous leachate, which could potentially leak from the landfill body was captured in the LP on the landfill site where the leachate quality was also monitored. Samples from the monitoring points were collected twice a year in April and in October from 2008 to 2013.

Table 1. Monitoring objects.

\begin{tabular}{ccc}
\hline Designation & Description & Localization \\
\hline MV-1 & Drill hole & Under landfill front \\
MV-2A & Drill hole & Landfill edge \\
MV-4 & Drill hole & Upper landfill edge \\
MV-5 & Drill hole & Upper landfill edge \\
ST-1 & Shaft ring well & Under landfill front \\
LP & Leachate pond & Western landfill edge \\
\hline
\end{tabular}

Each of drill holes (Table 1) had its singular significance. The MV-1 monitoring drill hole and the ST-1 shaft ring well were situated immediately under the landfill front in the direction of the groundwater flow, serving for the identification and quantification of the landfill operation's impact on the groundwater. The MV-2A monitoring drill hole was situated under a former field dunghill towards the landfill edge, in the direction of the groundwater flow. This drill hole served to identify a possible leachate from this space, which is still used for various purposes connected with agricultural production. The MV-4 and MV-5 monitoring drill holes were situated above the eastern edge of the landfill and were always used as reference points for the comparison of groundwater chemical composition in the space above the landfill (in the counter-direction to the groundwater table gradient), i.e., in the space not affected by the landfill, with the current status of area under the landfill. The LP was located at the western edge of the landfill and its main purpose was to retain waters leaking from the landfill body. 
2000

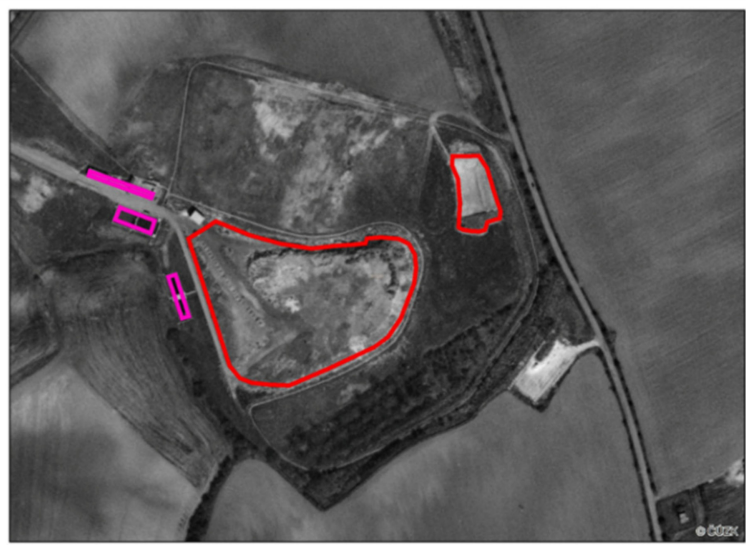

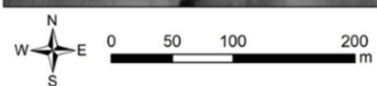

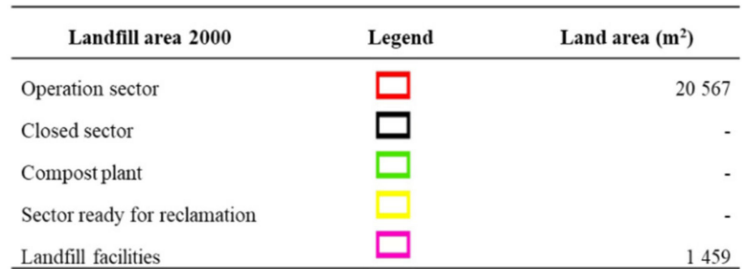

2012

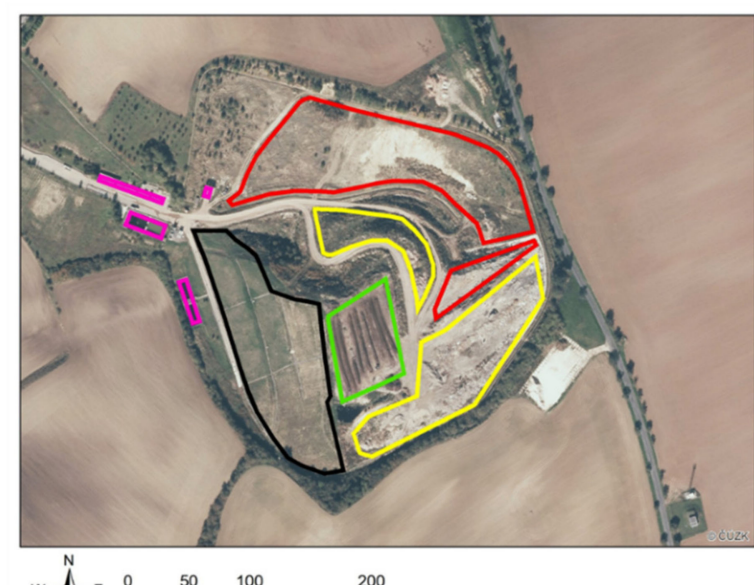

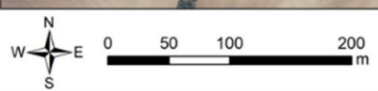

\begin{tabular}{lcr}
\hline \multicolumn{1}{c}{ Landfill area 2012 } & Legend & Land area $\left(\mathbf{m}^{2}\right)$ \\
\hline Operation sector & $\square$ & 16942 \\
Closed sector & $\square$ & 12645 \\
Compost plant & $\square$ & 4643 \\
Sector ready for reclamation & $\square$ \\
Landfill facilities & $\square$ & 13074 \\
\hline
\end{tabular}

2014

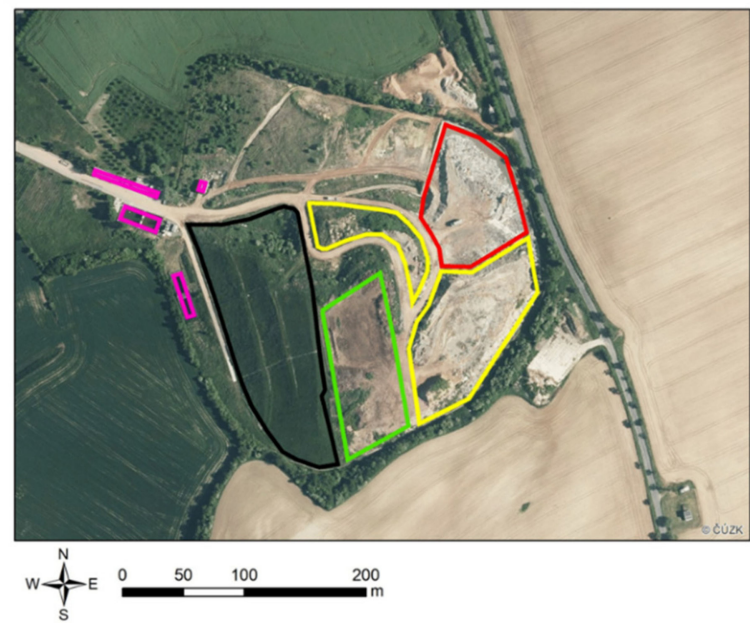

\begin{tabular}{lrr}
\hline \multicolumn{1}{c}{ Landfill area 2014 } & Legend & Land area $\left(\mathbf{m}^{2}\right)$ \\
\hline Operation sector & $\square$ & 7639 \\
Closed sector & $\square$ & 15773 \\
Compost plant & $\square$ & 7666 \\
Sector ready for reclamation & $\square$ \\
Landfill facilities & $\square$ & 13362 \\
\hline
\end{tabular}

Figure 2. Changes in the use of the respective landfill parts in the period of 14 years (2000-2014). The surface area of the respective parts of the landfill was determined based on the analysis of aerial photographs made by the Czech Office for Surveying, Mapping and Cadaster. 


\subsection{Chemical Analysis of Groundwater and Leachates}

The collected samples were cooled to a temperature of $4{ }^{\circ} \mathrm{C}$ and transported to the accredited laboratory Toma, Ltd. in Otrokovice for further analyses. Selected parameters were determined in compliance with internationally recognized methods (Table 2): $\mathrm{pH}, \mathrm{P}_{\text {tot }}, \mathrm{N}_{\text {tot }}, \mathrm{Cd}, \mathrm{Hg}, \mathrm{Zn}, \mathrm{Cr}, \mathrm{Pb}, \mathrm{Ni}$, As, chemical oxygen demand (COD), absorbable organic halogens (AOX), and polycyclic aromatic hydrocarbons (PAH) - $\mu \mathrm{g} \mathrm{L}^{-1}$ (ISO 7981:2005).

Table 2. Parameters determined in samples and methods used.

\begin{tabular}{ccc}
\hline Parameters & Unit & Method \\
\hline $\mathrm{pH}$ & - & ISO 10523 \\
$\mathrm{P}_{\text {tot }}$ & $\mathrm{mg} \mathrm{L}^{-1}$ & ISO 6878:2004 \\
$\mathrm{N}_{\text {tot }}$ & $\mathrm{mg} \mathrm{L}^{-1}$ & ISO 11905:1997 \\
$\mathrm{Cd}$ & $\mathrm{mg} \mathrm{L}^{-1}$ & DIN 38 406, TNV 757389 \\
$\mathrm{Hg}$ & $\mathrm{mg} \mathrm{L}^{-1}$ & TNV 75 7440 \\
$\mathrm{Zn}$ & $\mathrm{mg} \mathrm{L}^{-1}$ & DIN 38 406, TNV 757389 \\
$\mathrm{Cr}$ & $\mathrm{mg} \mathrm{L}^{-1}$ & ISO 11083:1994 \\
$\mathrm{Pb}$ & $\mathrm{mg} \mathrm{L}^{-1}$ & DIN 38 406, TNV 757389 \\
$\mathrm{Ni}$ & $\mathrm{mg} \mathrm{L}^{-1}$ & DIN 38 406, TNV 757389 \\
$\mathrm{As}$ & $\mathrm{mg} \mathrm{L}^{-1}$ & ISO 11885:2007 \\
$\mathrm{COD}$ & $\mathrm{mg} \mathrm{L}^{-1}$ & ISO 8467:1993 \\
$\mathrm{AOX}$ & $\mu \mathrm{g} \mathrm{L}^{-1}$ & ISO 9562:2004 \\
$\mathrm{PAH}$ & $\mu \mathrm{g} \mathrm{L}^{-1}$ & ISO 7981:2005 \\
\hline
\end{tabular}

\subsection{Leachate Toxicity Tests}

The leachates were sampled from the landfill LP each year of monitoring. The samples were subjected to two tests: a test of semichronic toxicity with the seeds of white mustard (Sinapis alba L.) and a test of leachate toxicity at the semichronic exposure of duckweed (Lemna minor L.).

\subsubsection{Test of Semichronic Toxicity with the Seeds of White Mustard (Sinapis alba L.)}

This test was designed to test the harmfulness of wastewaters. It was based on the germination of seeds (15 seeds) and the root growth of white mustard (Sinapis alba L.) as representative of cultural crops. The principle of the test consisted in the cultivation of seeds on mats saturated with leachate solutions of specific rates $(25 \%, 50 \%, 75 \%$ and $90 \%)$, which were placed in petri dishes (PD) and compared with seeds cultivated on PD with the nutrient solution. The samples prepared in this way were placed in the eco-cell incubator at a temperature of $25 \pm 2{ }^{\circ} \mathrm{C}$. After a lapse of 72 hours from the test establishment, root length was gauged for each rate and arithmetic means were determined from the obtained values. This procedure was identical in each repetition. Then the root growth inhibition (GI) was calculated for the respective rates as follows (1):

$$
G I(\%)=\frac{L(e)-L(t)}{L(e)} \times 100
$$

where GI is the root growth inhibition (\%), $L(t)$ is the average root length in the tested rate $(\mathrm{mm})$, and $L(e)$ is the average root length in the control $(\mathrm{mm})$.

\subsubsection{Test of Leachate Toxicity at the Semichronic Exposure of Duckweed (Lemna minor L.)}

Three rates of leachate were tested. The first rate was 10\% (LW 10) with $9 \mathrm{ml}$ of nutrient solution and $1 \mathrm{ml}$ of tested leachate in the PD. The second rate was 20\% (LW 20) with $8 \mathrm{ml}$ of nutrient solution and $2 \mathrm{ml}$ of tested leachate, and the third rate was 100\% (LW 100) of leachate. The reference standards were PD with $10 \mathrm{ml}$ of nutrient solution. Leaves of duckweed (Lemna minor L.; 9 fronds) were transferred into the PD using tweezers. The prepared samples were placed in a room with constant lighting and 
temperature $24 \pm 2{ }^{\circ} \mathrm{C}$ for 7 days. After the end of the testing time, the growth rate and subsequently GI were calculated. The number of fronds at the beginning, during and at the end of the test were used to calculate the growth rates for the control and for the respective leachate rates using the following Equation (2):

$$
\mu=\frac{\ln N_{n}-\ln N_{0}}{t_{n}}
$$

where $\mu$ is the growth rate, $\mathrm{N}_{0}$ is the number of fronds at the beginning of the test, $\mathrm{N}_{\mathrm{n}}$ is the number of fronds at the end of the test, and $t_{n}$ is the test duration.

The GI determination was based on the values of the growth rate. The GI was calculated from the obtained data for each tested leachate rate. If the resulting GI $>0$, we could speak of GI; if GI $<0$, it was growth stimulation. The GI calculation formula (3) was as follows:

$$
G I=\frac{\left(\mu_{e}-\mu_{t}\right)}{\mu_{e}} \times 100
$$

where GI is the growth inhibition for the given leachate rate (\%), $\mu_{e}$ is the growth rate recorded in the control sample, and $\mu_{t}$ is the growth rate in the tested leachate rates.

\subsection{Data Treatment and Statistical Analysis}

Multivariate statistical methods are useful for the interpretation and modeling of large data sets. In the presented study, the following analyses were used: analysis of variance (ANOVA) and principal component analysis (PCA). SPSS-19 (IBM, Amonk, New York, USA) and Dell Statistica 12 (Dell, Round Rock, Texas, USA) programs were used to analyze the data. The ANOVA method evaluates the relative size of variance between group means compared to the average variance within groups [22]. A one-way ANOVA combined with the post-hoc Tukey's HSD test was used to identify significant differences within the data set.

PCA represents a technique used to reduce measured variables and is the method most widely used in factor analysis $[23,24]$. The principal components (PCs) are calculated mathematically from covariance or other cross-product matrices that explain the distribution of multiple measured parameters in order to obtain eigenvector and eigenvalues. Primary components are linear combinations of eigenvectors and original variables. Varimax normalization is used to evaluate the results of statistical analysis [23,24]. In this study, eigenvalue greater than 1 was considered significant [24-26]. Above all, varimax normalization was performed to better explain the results.

\section{Results and Discussion}

\subsection{General Evaluation of Parameters Measured in Groundwater and Leachate}

The content of HMs in groundwater and leachate can be evaluated from several perspectives both as the mean values for individual years (Figure 3) and as the mean values for the whole period of monitoring (2008-2013) (Figure 4A,B). The measured values revealed several results. Firstly, more profound concentrations of $\mathrm{HMs}$ (Figure 3A) were found only in $\mathrm{Ni}, \mathrm{Zn}$ and $\mathrm{Cr}$, with the values regularly exceeding the limit of $0.1 \mathrm{mg} \mathrm{L}^{-1}$, which could be considered significant with respect to the sensitivity of methods used. Other $\mathrm{HMs}$ such as, $\mathrm{Pb}, \mathrm{Hg}$ and $\mathrm{Cd}$ (Figure 3B) were most of the time present in very low concentrations $<0.07 \mathrm{mg} \mathrm{L}^{-1}$. Secondly, no significant differences $(\mathrm{P}<0.05)$ were observed among the respective monitoring drill holes (Figure 4), only between all drill holes and the LP. Thirdly, neither the date nor the year of sampling had a significant influence on the concentrations of the selected HMs in the samples. This was also corroborated by the ANOVA results (Appendix A Tables A1 and A2) which did not indicate any significant differences. The measured values showed only partial differences between the individual drill holes and the well. By contrast, the concentration of HMs measured in the LP reached demonstrably $(P<0.05)$ the highest values. 
A
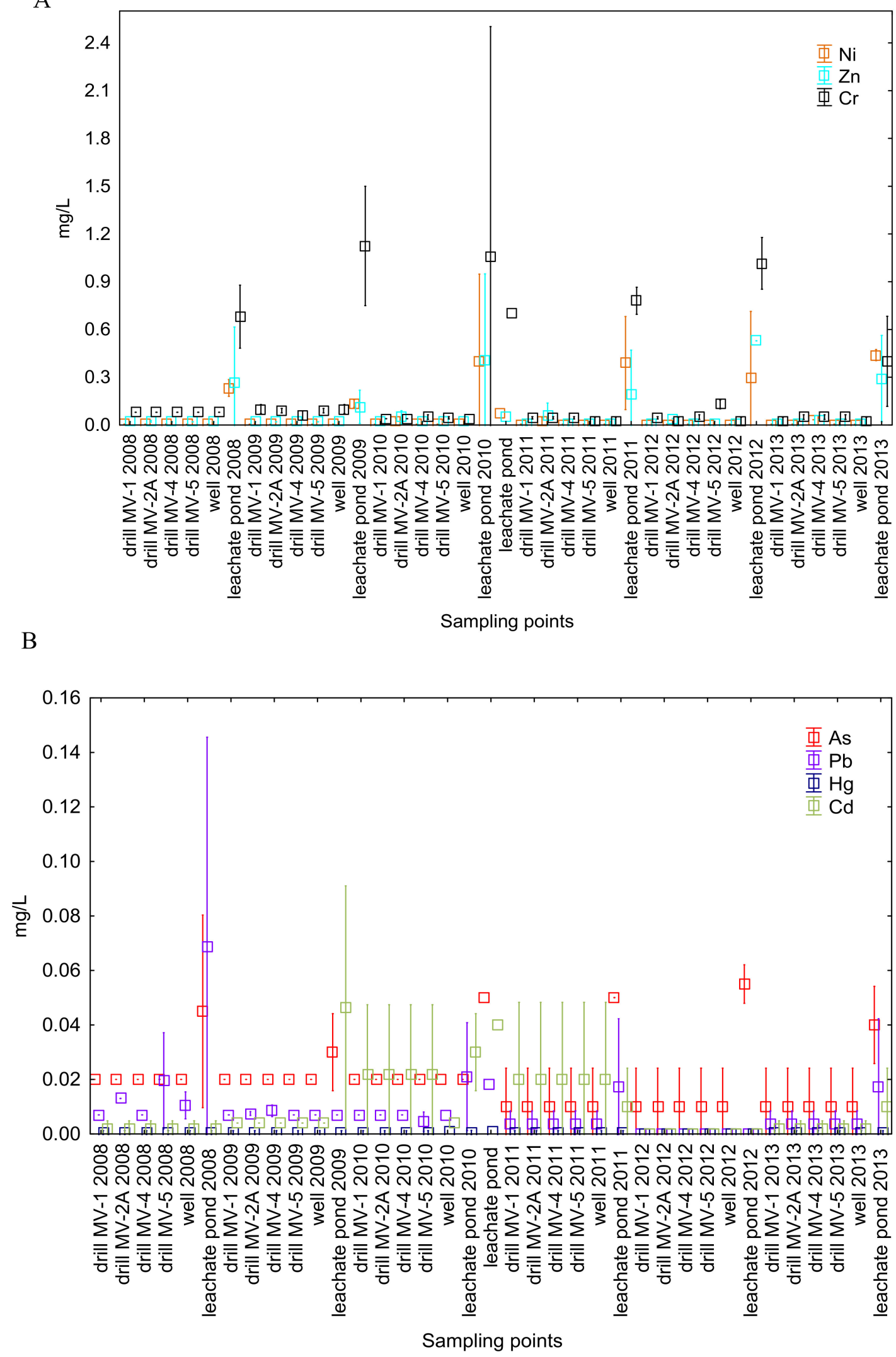

Figure 3. Average contents of selected HMs (A and B) in the monitoring points in 2008-2013. 


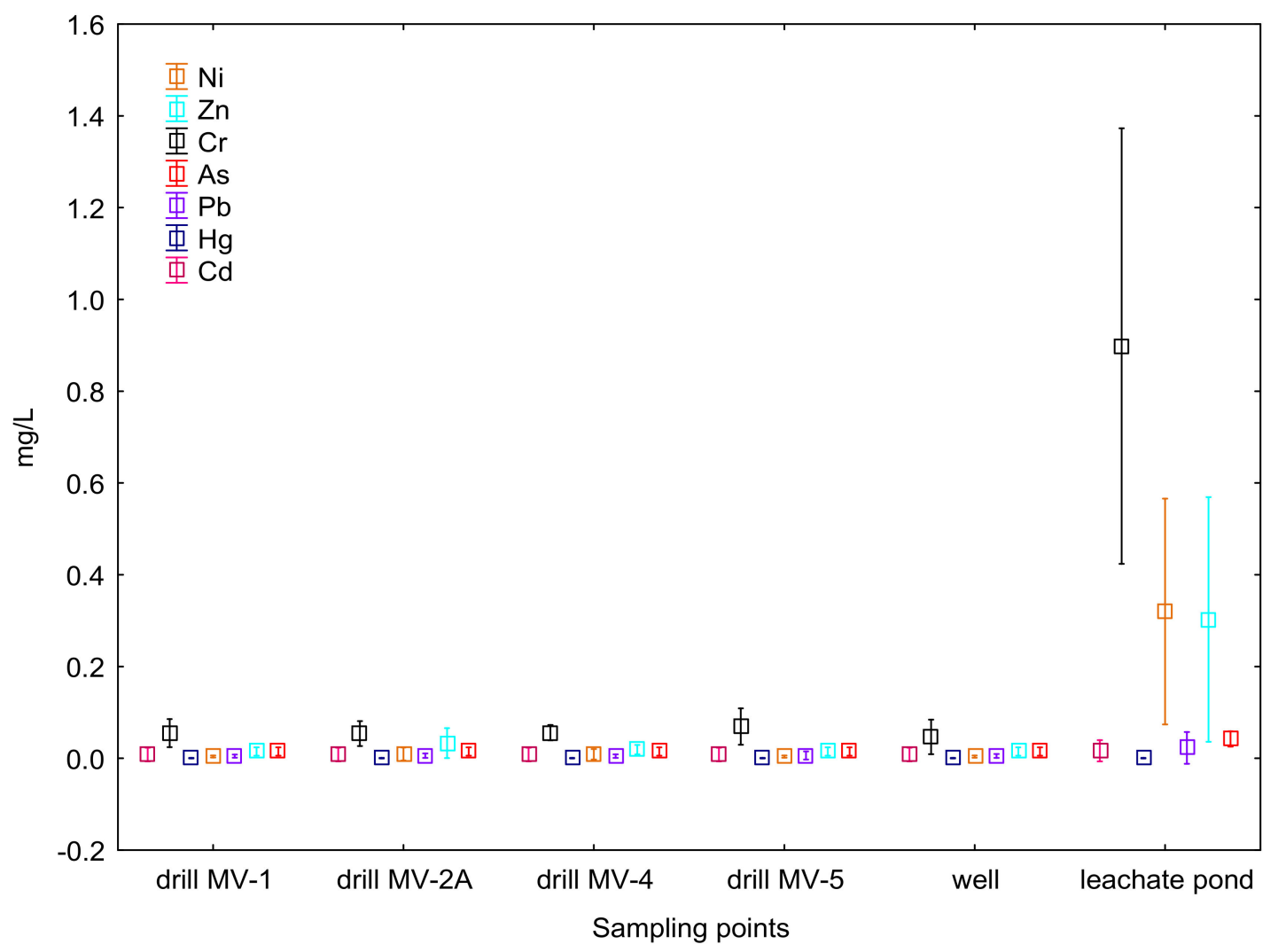

Figure 4. Average concentrations of HMs in the monitoring points for the period of five years (2008-2013).

Increased concentrations were found only in three HMs: $\mathrm{Ni}, \mathrm{Zn}$ and $\mathrm{Cr}$. The other $\mathrm{HMs}$ were on the limit of determination. Based on the previous scientific studies of [27-29], the concentration of HMs was chosen as a major indicator of possible adverse effects of the hypothetical leakage of contaminated leachates from the landfill body. The values of $\mathrm{Ni}, \mathrm{Zn}$ and $\mathrm{Cr}$ measured in the monitoring drill holes (MV-1, MV-2A, MV-4, MV-5 and the well) indicated that groundwater contamination with HMs was not increased. Only one significant difference was found in the concentration of Ni between MV-4 and the remaining drill holes. The measured values were in accordance with those found by Olafisoye et al. and Chen et al. [30,31], who consider $\mathrm{Ni}, \mathrm{Zn}$ and $\mathrm{Cr}$ concentrations $<0.1 \mathrm{mg} \mathrm{L}^{-1}$ acceptable and not representing a profound danger to the surrounding environment. Furthermore, it can be assumed that the number of leachates will decrease with the shrinking area of the active landfill part (Figure 2), which was reduced by more than 5\% in the period from 2000 to 2014. The reason for this is that the reclaimed part of the formerly active landfill is able to retain a greater amount of precipitation in the landfill surface layers (because of the vegetation) and the amount of leachates will be lower than in the open landfill body.

The below comparison with the World Health Organization (WHO) limits (2011 and 2017) [32,33] in Table 3 shows clearly that the measured $\mathrm{Ni}, \mathrm{Zn}$ and $\mathrm{Cr}$ concentrations were higher in the LP when compared with those in the drill holes and in the shaft ring well. These increased HMs concentrations in the measuring point of LP demonstrate that the mechanisms preventing HMs leaks from the landfill into the surrounding environment function properly. The most important measure is seen in the landfill insulation layer, which prevents HMs leakage into groundwater. The LP water exhibited the highest concentrations of $\mathrm{Ni}, \mathrm{Zn}$ and $\mathrm{Cr}$ (ranging from 0.3 to $0.9 \mathrm{mg} \mathrm{L}^{-1}$ ) in the respective years of monitoring (Figure 3; 2008-2013) as well as average concentrations of HMs for the whole monitoring period (Figure 4; 2008-2013). 
Table 3. Comparison of average HMs contents in the monitoring points for the period of five years with the WHO limits for drinking water.

\begin{tabular}{ccccccccc}
\hline & \multicolumn{7}{c}{ HMs Concentration (mg L $\mathbf{~}^{-1}$ ) } \\
\cline { 2 - 8 } & $\mathbf{M V - 1}$ & MV-2A & MV-4 & MV-5 & Well & LP & Limit Value (WHO, 2011) [32] & Limit Value (WHO, 2017) [33] \\
\hline $\mathrm{Ni}$ & $0.05^{\mathrm{a}}$ & $0.01^{\mathrm{a}}$ & $0.09^{\mathrm{b}}$ & $0.05^{\mathrm{a}}$ & $0.05^{\mathrm{a}}$ & $0.3^{\mathrm{c}}$ & 0.07 & 0.07 \\
$\mathrm{Zn}$ & $0.02^{\mathrm{a}}$ & $0.03^{\mathrm{a}}$ & $0.02^{\mathrm{a}}$ & $0.02^{\mathrm{a}}$ & $0.03^{\mathrm{a}}$ & $0.31^{\mathrm{b}}$ & 3 & 1 \\
$\mathrm{Cr}$ & $0.05^{\mathrm{a}}$ & $0.05^{\mathrm{a}}$ & $0.06^{\mathrm{a}}$ & $0.07^{\mathrm{a}}$ & $0.05^{\mathrm{a}}$ & $0.89^{\mathrm{b}}$ & 0.05 & 0.05 \\
\hline
\end{tabular}

Note: Different small letters indicate significant $(P<0.05)$ differences in content of individual HMs between individual sampling points.

The contents of P and N (Figure 5) and COD, AOX and PAH were also monitored (Figure 6).

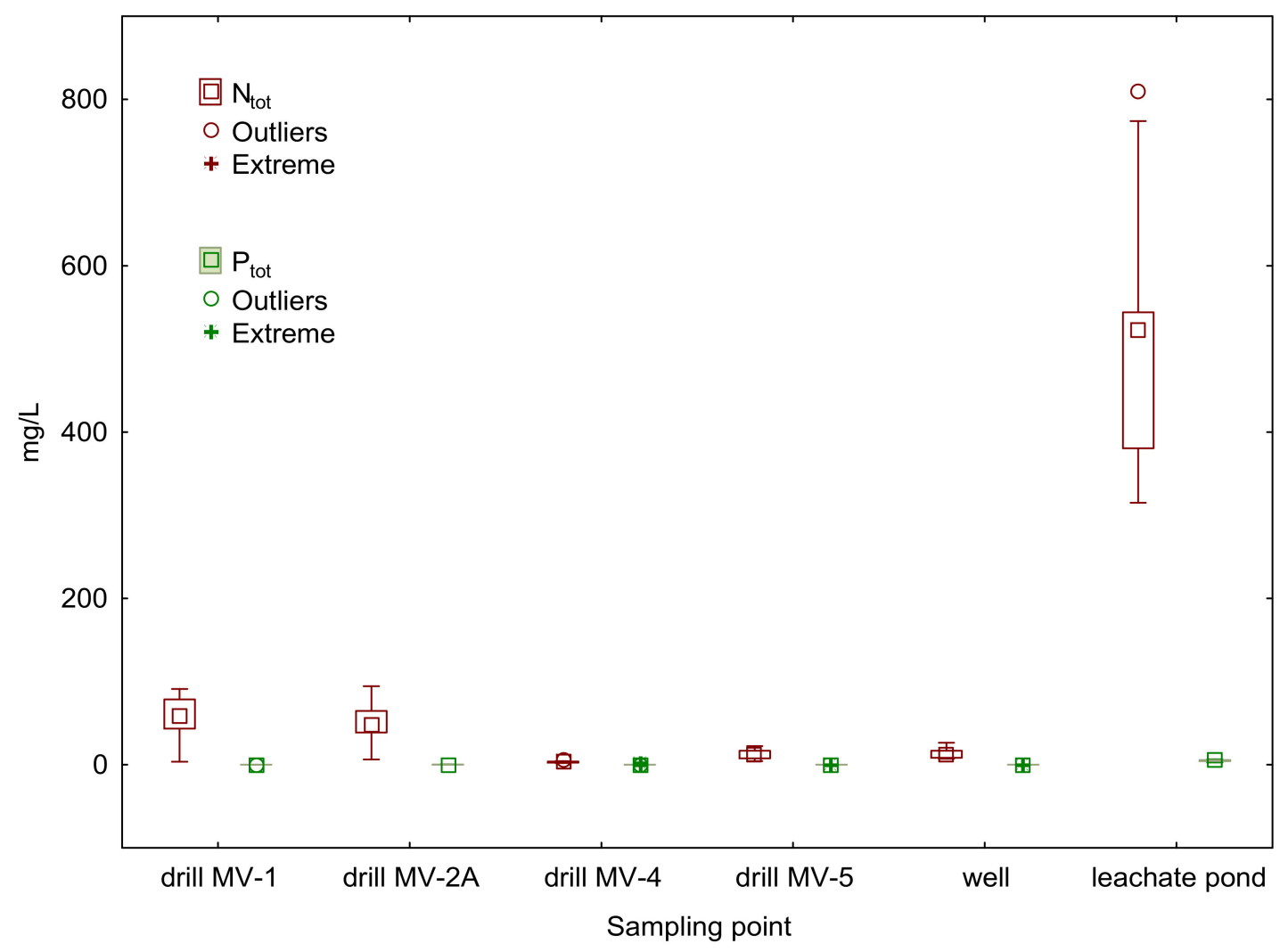

Figure 5. Boxwhisker plot graphs of $\mathrm{P}_{\text {tot }}$ and $\mathrm{N}_{\text {tot }}$ for the respective sampling points in the period of five years (2008-2013). 

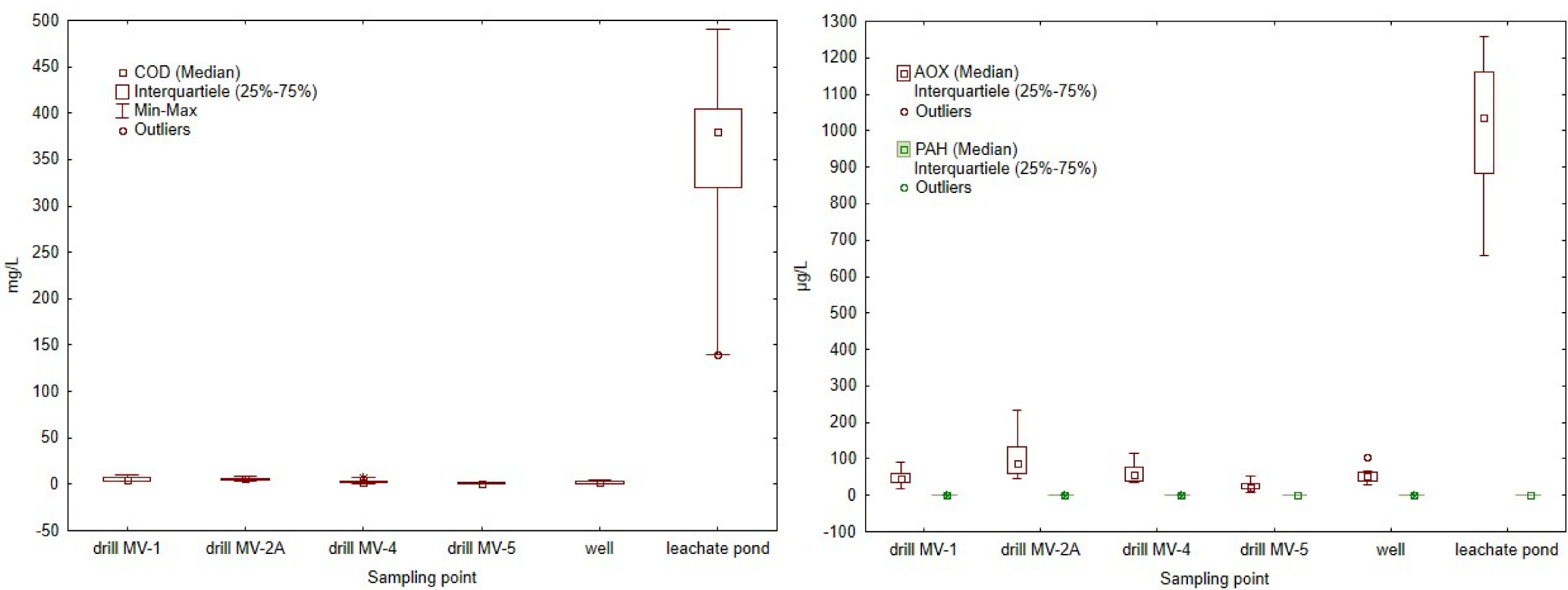

Figure 6. Boxwhisker plot graphs of chemical oxygen demand (COD), absorbable organic halogens (AOX), and polycyclic aromatic hydrocarbons (PAH) for the respective sample points in the five-year period (2008-2013). 
These supplementary indicators may point to other potential adverse effects on the environment in the case of possible leakages. Based on the presence of AOX and PAH in the leachates, the origin of the HMs can be determined because, for example, AOX occur most frequently in leachates that have come into contact with cellulose- and ash-based waste from MSW incinerators [34,35]. On the other hand, the values of COD and the contents of biogenic elements ( $\mathrm{N}$ and $\mathrm{P}$ ) may indicate the organic origin of leachate pollution. The values of $\mathrm{P}_{\text {tot }}$ content ranged up to $10 \mathrm{mg} \mathrm{L}^{-1}$ with no significant differences among the respective monitoring points. Based on these values, it can be stated that runoff from adjacent fields did not reach the landfill body (Figure 1; Appendix A Figure A1), which is also indicated by runoff lines directed away from the landfill. Another reason may be the generally low mobility of P substances [36-38] inhibiting their possible washout from the landfill body in the case of their presence therein. In the drill holes and shaft ring well, the mean $\mathrm{N}_{\text {tot }}$ value did not exceed the boundary of $60 \mathrm{mg} \mathrm{L}^{-1}$; by contrast, in the MV-2A, MV-4, MV-5 monitoring points and in the well, it dropped below $50 \mathrm{mg} \mathrm{L}^{-1}$. For comparison, the Drinking Water Directive of the European Union (EU) (98/83/EC) sets the value of $50 \mathrm{mg} \mathrm{L}^{-1}$ as the limit for the content of nitrates in drinking water. The value of $\mathrm{N}_{\text {tot }}$ in the above-mentioned sampling points did not exceed the set limit with the exception of MV-1, where the detected concentration was $58 \mathrm{mg} \mathrm{L}^{-1}$. These values indicate that there were no leakages of organic pollutants from the landfill body. Moreover, Appendix A Figure A2 contains information about the concentration of the individual form of $\mathrm{N}$ and nitrate $\mathrm{N}$, which represents more than $95 \%$ of the $\mathrm{N}_{\text {tot }}$ within all variants except for the LP. On the contrary, the analysis of samples for the period from 2008 to 2013 revealed an increased content of $N_{\text {tot }}$ in the LP. And only $10 \%$ of this content was formed by mineral forms of $\mathrm{N}$. This indicates that the LP held not only the leachate from the landfill but also surface flushes from the individual landfill parts. Together with the concentrations of HMs, this value confirmed once again that the landfill had been designed properly, and possible leachates were captured by the insulation layer and drained into the LP. This was also corroborated by the COD values, which were minimal in all monitoring objects $\left(<3 \mathrm{mg} \mathrm{L}^{-1}\right)$ except for the LP, where they ranged from 140 to $490 \mathrm{mg} \mathrm{L}^{-1}$ in the studied period. The COD parameter serves to determine an ideal amount of $\mathrm{O}_{2}$ that would be required for oxidation of all organic substances in water. Thus, its value is directly proportional to the content of potential OP indicators (Oxygen indicators: COD; AOX and Polyromantic indicator: PAH) in water [39-41]. In the EU, the limits for drinking water and treated wastewater are $3 \mathrm{mg} \mathrm{L}^{-1}$ and $55 \mathrm{mg} \mathrm{L}^{-1}$, respectively (Directives 91/271/EEC and 2000/60/EC). Natural sources mostly exhibit values from 100 to $60,000 \mathrm{mg} \mathrm{L}^{-1}$ [39-41]. Therefore, we can claim that the COD values measured in the monitoring points exhibited no contamination by pollutants of organic origin.

The AOX and PAH contents were monitored, too (Figure 6). The AOX parameter indicates the content of organic substances binding some elements from the group of halogens. These substances are potentially toxic, especially for aquatic ecosystems [35,40]. A description of their impact on human health is complicated because AOX represents a wide group of substances with diverse impacts [41]. The average values measured in all drill holes and in the well did not exceed $60 \mu \mathrm{g} \mathrm{L}^{-1}$. The values measured in the respective monitoring objects (with the exception of LP) ranged from a minimum of 8.5 to a maximum of $232 \mu \mathrm{g} \mathrm{L}{ }^{-1}$ with no statistically significant differences among the monitoring objects. There was no evidence that the values would be directly affected by waste landfilling. The substances of the AOX group can be generated naturally, too, for instance by enzymes produced by microorganisms [42].

As to the AOX concentration, an exception was the LP, in which the mean value for the period from 2008-2013 reached $1000 \mu \mathrm{g} \mathrm{L}^{-1}$ and the values detected during the monitoring ranged from 650 to 1260 . The PAH content was also monitored. An increased PAH concentration would have indicated the increased presence of waste from powerplants and other incineration facilities and asphalt mixtures in the landfill body [43]. This was not confirmed because the measured PAH values were at the limit of detection, i.e., around $0.09 \mathrm{mg} \mathrm{L}^{-1}$. No differences were observed among the monitored objects.

The measured concentrations of HMs exceeded the value of $0.01 \mathrm{mg} \mathrm{L}^{-1}$ only in $\mathrm{Ni}$, $\mathrm{Zn}$ and $\mathrm{Cr}$. The increased values $\left(>1 \mathrm{mg} \mathrm{L}^{-1}\right)$ were detected only in the LP. The monitoring drill holes as well as 
the shaft ring well exhibited at all times the values of these HMs below $0.2 \mathrm{mg} \mathrm{L}^{-1}$, which represented no risk [27]. It is important to take into account the landfill location on an elevated site in the given locality (Figure 1; Appendix A Figure A1). Should the landfill construction have some defects, namely in terms of insulation (the prevention of leachate leakage), the transportation of measured substances (HMs, PAH, AOX) into the surrounding lands would have occurred [44] because all runoff lines are directed into the adjacent farmlands (Appendix A Figure A1). The direction of surface and sub-surface runoffs is plotted in Figure 1 and in Appendix A Figure A1 as blue dot-dash arrows. Nevertheless, the measured values disproved such a scenario because the monitoring drill holes did not exhibit increased values of the parameters.

\subsection{Relationship between the Individual Measured Parameters}

The strength of the potential relations among the respective parameters was determined through the correlation analysis at a significance level of $P<0.05$. The correlation matrix of data obtained from the PCA is shown in Appendix A Table A3. The PCA analysis results are given in Appendix A Table A4. A graphical representation of the correlation of each parameter is given in Appendix A Figure A3. There was a significant and positive relationship between $\mathrm{pH}$ and $\mathrm{P}_{\text {tot }}, \mathrm{N}_{\mathrm{tot}}, \mathrm{Cd}, \mathrm{AOX}, \mathrm{Zn}, \mathrm{Cr}, \mathrm{Pb}, \mathrm{Ni}$, COD, As, PAH ( $\mathrm{r}=0.505-0.877)$. There was also a significant and positive correlation between $\mathrm{P}_{\text {total }}$ and $\mathrm{N}_{\text {total }}, \mathrm{Zn}, \mathrm{Cr}, \mathrm{Pb}, \mathrm{Ni}, \mathrm{As}, \mathrm{COD}, \mathrm{PAH}, \mathrm{AOX}(\mathrm{r}=0.501-0.968)$. A clear dependence was observed of the presence of organic substances in the leachate and the presence of most HMs. In particular, a significant and positive relationship was found between $\mathrm{AOX}$ and $\mathrm{pH}, \mathrm{P}_{\text {tot }}, \mathrm{N}_{\mathrm{tot}}, \mathrm{Cd}, \mathrm{Zn}, \mathrm{Cr}, \mathrm{Pb}, \mathrm{Ni}$, As, COD, PAH, $(\mathrm{r}=0.508-0.963)$. These significant correlations again indicate a relationship between the organic sources of pollution and the other pollutants (AOX and HMs). Another significant and positive relationship was detected between $\mathrm{Zn}$ and $\mathrm{pH}, \mathrm{P}_{\text {tot }}, \mathrm{N}_{\text {tot }}, \mathrm{AOX}, \mathrm{Zn}, \mathrm{Cr}, \mathrm{Pb}, \mathrm{Ni}, \mathrm{As}, \mathrm{COD}, \mathrm{PAH}$, $(r=0.578-0.834)$. Furthermore, all measured values confirmed that the AOX concentration correlated with leachate characteristics like $\mathrm{pH}, \mathrm{P}_{\text {tot }}$ and $\mathrm{N}_{\text {tot }}$ content. Also, a strong relationship was found between AOX and HMs concentration in the leachate. The other parameters of correlation results are given in Appendix A Table A3. The dependence between the presence of organic substances in leachates and the content of HMs corroborated conclusions published by Tchounwou et al. [45], and Przydatek et al. [46], which point out the possible binding of HMs to organic substances, the reason being the high density and atomic mass of HMs. Thus, it can be assumed that, should an increased amount of organic substances be detected in the adjacent drill holes reaching into groundwater, this would be accompanied also by increased concentrations of HMs. This, however, did not happen; OP indicators were at minimum levels for all drill holes and the well (Figure 5; Figure 6) as well as the concentrations of HMs (Figure 4) in the monitoring points for the period 2008-2013.

The analyzed relationships between the individual parameters suggest that a positive correlation existed between the content of organic substances $\left(\mathrm{P}_{\text {tot }}\right.$ and $\left.\mathrm{N}_{\text {tot }}\right)$ in the analyzed samples and the concentrations of most $\mathrm{HMs}(\mathrm{Cd}, \mathrm{Zn}, \mathrm{Cr}, \mathrm{Pb}, \mathrm{Ni}, \mathrm{As})$. A similar positive correlation was observed between the COD, PAH, AOX and HMs. The given parameters, $\mathrm{P}_{\text {tot }}, \mathrm{N}_{\text {tot }}$ and COD in particular, directly indicated the presence of organic substances in water [38,39]. The results from the LP indicate that, in addition to mineral substances, the landfill body also contained substances of organic nature to which HMs may potentially bind that subsequently can be washed out [47]. However, the increased values (particularly those of $\mathrm{N}_{\text {tot }}$ and COD) were measured only in the LP. In the monitoring objects, the values of these parameters ranged at very low levels (Figure 6). Hence, there was no groundwater contamination, nor any leakage of hazardous substances into the surrounding farmlands.

\subsection{Factors Affecting the Occurrence of HMs, PAHs and AOX in Leachates}

A PCA was used to detect the factors possibly affecting the presence of the selected indicators in leachates and in water collected from the monitoring objects. The suitability for the factor analysis of measured data was tested by the Kaiser-Meyer-Olkin (KMO) and Bartlett tests. The value of KMO should be greater than 0.5 . Therefore, the data are suitable for the factor analysis when the KMO value 
gets closer to 1 between 0 and $1[48,49]$. According to results of the analysis, the value of $K M O=0.733$ was suitable for being used in the analysis of measured data. As a result of the factor analysis, three main factors (Appendix A Table A4) were identified. These three factors explained for $80.8 \%$ of the total variance. The main two factors (F1 and F2), explaining for more than $70 \%$ of the total variance, are graphically represented using the plot of scores in Appendix A Figure A3. It was concluded that the variability $(>70 \%)$ was caused by industrial and household pollution sources.

\subsection{Phytotoxicity Parameters of Leachate Water}

The results of the GI by leachates are presented in Appendix A Figure A3. In the experimental period, leachates inhibited the model plant root growth at all tested rates. The average root GI in the model plant was $62.72 \%, 91.50 \%, 98.38 \%$, and $99.76 \%$ for the leachate rates of $25 \%, 50 \%, 75 \%$, and $90 \%$, respectively. The measured data indicate that the increasing rate of leachate in the test had an increasingly inhibitory effect on the growth of white mustard (Sinapis alba L.) roots.

The results of the GI at the semichronic exposure of duckweed (Lemna minor L.) in the period of monitoring are presented in Appendix A Figure A4. In the experimental period, all tested leachate rates $(10 \%, 20 \%$, and $100 \%)$ showed GI because all average values of GI $>0(40.26 \%, 83.01 \%$, and $100 \%$, respectively). The results indicate that the increasing rate of leachate in the test had an increasingly inhibitory effect on the growth of duckweed (Lemna minor L.). It was found in both model plants that the increasing concentration of leachates in the environment (i.e., with irrigation) was increasing their phytotoxicity. Similar results were published by Cheng et al. [50]. However, for example Guerrero-Rodríguez et al., [51] argue that in testing the impact of leachates on soil environment toxicity and yield of Phaseolus vulgaris L., a dependence was found between the phytotoxic effect and the leachate dilution. If the leachate was added to irrigation water, the yield of Phaseolus vulgaris L. grains decreased; however, the lowest yield was recorded in variants with the lowest dilution. In addition to this, the effect of grain crops and maize irrigation with leachate water was studied, with no demonstrable conclusions for the grain crops in terms of phytotoxicity [51] and with no effect observed in maize [52]. As to the measured laboratory values, it can be stated that the leachates from the experimental landfill might represent a problem in the agricultural area. On the other hand, the impact of the leachates for example on grain crops [51], which represent the main agricultural crop in the studied area, has not yet been comprehensively characterized. Thus, the leachates can exhibit phytotoxicity in laboratory conditions, while their action in the field can be different, i.e., no adverse effect on cultivated plants. Their concentration in the soil environment can also be decisive [50].

\subsection{Possible Landfill Impact on the Agricultural Area}

Literature reviews indicate that the impact on crops may result from the potential leaks through the base sealing layers into groundwater, surface runoff of rainwater and dust fall in dry periods [14,15]. Studies performed by Kaszubkiewicz et al. [53] revealed that soils in the surroundings of legal landfills did not show any increased HMs content compared to the background. The presented study showed no HMs accumulations occurring in the soil-water environment near the landfill (Figure 3). Moreover, Jahan et al. [54] stated that if the landfill site is effectively managed, there is no objection to using the areas surrounding the landfill for agricultural production. Tracking the transport and fate of HMs near the landfill area is also important because soils can absorb leachate constituents. As a result, HMs absorbed by the soil can be easily taken up by plants. Subsequently this state is manifested by an effect on the growth and productivity of crops as well as on human and animal health [55]. Equally worth emphasizing is the monitoring of ammonium concentration in the leachate and its impact on the surrounding agricultural areas [54-56]. This is important because during their migration through the soil profile to deeper horizons they can contaminate underground sources of water [56]. Since agricultural areas are permanently exposed to $\mathrm{N}$ pollution due to the widespread use of $\mathrm{N}$ fertilizers in agricultural practice [54-58], attention should be given to minimizing the load of $\mathrm{N}$ compounds from external sources, including landfills and WM facilities. 
The effect of leachate on higher plants (Sinapis alba L. and Cannabis sativa L.) was studied by Zloch et al. [14,18]. Phytotoxicity tests of concentrated leachate confirmed a GI higher than 90\% (Sinapis alba L.). A GI between $21.1 \%$ and $89.8 \%$ (depending on precipitation and month of sampling) was found when testing the leachate using Cannabis sativa L. The tests clearly showed that susceptibility of higher plants to noxious agents is high and wastewater leakage into the environment might have fatal health consequences.

The surveys of groundwater quality showed no direct impact of pollution currently affecting groundwater quality (Figure 1 and Appendix A Figure A1). An indirect impact may be landfill dust fall on the surrounding agricultural crops. The actual impact on vegetation and its composition can be ascertained after tests, sampling and testing of groundwater samples from piezometers installed at a greater distance from the landfill. In setting up the installation distances of piezometers for groundwater monitoring, both groundwater flow directions and soil permeability (runoff lines on arable land surrounding the landfill are illustrated in Appendix A Figure A1) should be taken into account. The potential impact of landfills located in agricultural areas can be exactly determined only through the extended scope of monitoring, including vegetation surveys.

\section{Conclusions}

The water quality and the quality of leachates from the landfill body were monitored in the selected monitoring objects of municipal solid waste landfill. The monitoring points were drill holes reaching into the groundwater outside the landfill body. The leachates from the landfill are captured in the leachate pond and further disposed. The quality of the groundwater and leachates was evaluated based on the contents of heavy metals, $\mathrm{N}_{\text {tot }}, \mathrm{P}_{\text {tot }}$, polycyclic aromatic hydrocarbons and absorbable organic halogens. In addition, $\mathrm{pH}$ and chemical oxygen demand values were measured. According to the analysis results and tests indicating the presence of statistically significant differences in the measured parameters for each sampling point, no significant differences were recorded between the years and months. Statistical differences were found between individual variants in the concentrations of $\mathrm{Cr}, \mathrm{Ni}$ and $\mathrm{Zn}$, but only between the drill holes and the leachate pond, except in one case. The results showed that contaminated water collected in the leachate pond did not leak outside the landfill because the concentrations of heavy metals were minimal in the drill holes outside the landfill body. The leachates were found to be phytotoxic. The tests of semichronic toxicity with the seeds of white mustard (Sinapis alba L.) and leachate toxicity at semichronic exposure of duckweed (Lemna minor L.) demonstrated that the increasing rates of leachates result in their increasing inhibition effect.

Author Contributions: Conceptualization, M.D.V. and D.A.; methodology, D.A. and E.K.; validation, M.D.V., J.E., V.L., and J.E.; formal analysis, J.E., A.P., D.A., M.B., M.W. and A.B.; investigation, J.Z., A.P., and V.L.; data curation, J.Z., A.P., V.L., D.A., and A.B.; writing — original draft preparation, J.E., A.K.; writing-review and editing, M.D.V.; visualization, M.D.V., M.W. and J.E.; supervision, E.K.; project administration, A.K.; All authors have read and agreed to the published version of the manuscript.

Acknowledgments: The research was funded by the Ministry of Agriculture of the Czech Republic, institutional support MZE-RO1720.

Conflicts of Interest: The authors declare no conflict of interest 


\section{Appendix A}

Table A1. The results of the analysis of variance (ANOVA) in the respective years of monitoring.

\begin{tabular}{ccccccc}
\hline & & Sum of Squares & df & Mean Square & F & Sig. (P) \\
\hline $\mathrm{pH}$ & Between Groups & 0.67 & 5 & 0.13 & 0.51 & 0.77 \\
$\mathrm{P}_{\text {tot }}$ & Between Groups & 1.33 & 5 & 0.27 & 0.08 & 1.00 \\
$\mathrm{~N}_{\text {tot }}$ & Between Groups & $16,112.92$ & 5 & 3222.58 & 0.08 & 0.99 \\
$\mathrm{Cd}$ & Between Groups & 0.00 & 5 & 0.00 & 0.68 & 0.64 \\
$\mathrm{Hg}$ & Between Groups & 0.00 & 5 & 0.00 & 1.00 & 0.42 \\
$\mathrm{Zn}$ & Between Groups & 0.04 & 5 & 0.01 & 0.33 & 0.89 \\
$\mathrm{Cr}$ & Between Groups & 0.23 & 5 & 0.05 & 0.33 & 0.89 \\
$\mathrm{~Pb}$ & Between Groups & 0.00 & 5 & 0.00 & 0.69 & 0.63 \\
$\mathrm{Ni}$ & Between Groups & 0.03 & 5 & 0.01 & 0.23 & 0.95 \\
$\mathrm{As}$ & Between Groups & 0.00 & 5 & 0.00 & 0.24 & 0.94 \\
$\mathrm{COD}$ & Between Groups & 4407.33 & 5 & 881.47 & 0.04 & 1.00 \\
$\mathrm{PAH}$ & Between Groups & 0.02 & 5 & 0.00 & 0.13 & 0.98 \\
$\mathrm{AOX}$ & Between Groups & $59,153.47$ & 5 & $11,830.69$ & 0.08 & 0.99 \\
\hline
\end{tabular}

Note: The results of the analysis of variance (one-way ANOVA) of all measured parameters from 2008-2013. ANOVA was calculated at a significance level $P<0.05$.

Table A2. Results of ANOVA analysis in the respective months of monitoring.

\begin{tabular}{ccccccc}
\hline & & Sum of Squares & df & Mean Square & F & Sig. (P) \\
\hline $\mathrm{pH}$ & Between Groups & 0.01 & 1 & 0.01 & 0.06 & 0.81 \\
$\mathrm{P}_{\text {tot }}$ & Between Groups & 0.71 & 1 & 0.71 & 0.22 & 0.64 \\
$\mathrm{~N}_{\text {tot }}$ & Between Groups & $10,236.18$ & 1 & $10,236.18$ & 0.27 & 0.60 \\
$\mathrm{Cd}$ & Between Groups & 0.00 & 1 & 0.00 & 0.41 & 0.52 \\
$\mathrm{Hg}$ & Between Groups & 0.00 & 1 & 0.00 & 1.00 & 0.32 \\
$\mathrm{Zn}$ & Between Groups & 0.01 & 1 & 0.01 & 0.40 & 0.53 \\
$\mathrm{Cr}$ & Between Groups & 0.00 & 1 & 0.00 & 0.03 & 0.87 \\
$\mathrm{~Pb}$ & Between Groups & 0.00 & 1 & 0.00 & 1.79 & 0.19 \\
$\mathrm{Ni}$ & Between Groups & 0.04 & 1 & 0.04 & 1.65 & 0.20 \\
$\mathrm{As}$ & Between Groups & 0.00 & 1 & 0.00 & 0.30 & 0.58 \\
$\mathrm{COD}$ & Between Groups & 682.04 & 1 & 682.04 & 0.04 & 0.85 \\
$\mathrm{PAH}$ & Between Groups & 0.00 & 1 & 0.00 & 0.00 & 0.96 \\
$\mathrm{AOX}$ & Between Groups & 5361.30 & 1 & 5361.30 & 0.04 & 0.84 \\
\hline
\end{tabular}

Note: The results of the analysis of variance (one-way ANOVA) of all measured parameters for each sampling date in 2008-2013. ANOVA was calculated at a significance level $P<0.05$.

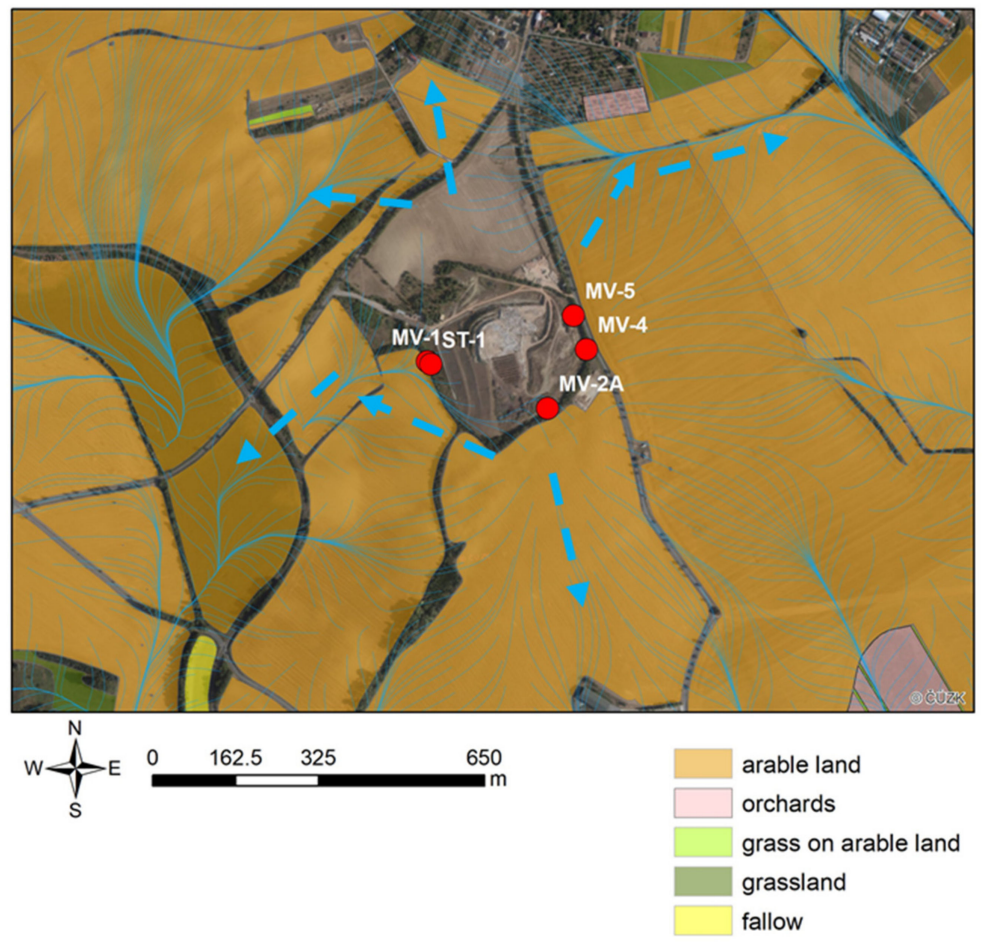

Figure A1. Runoff lines and farmland use in the close surroundings of landfill. 


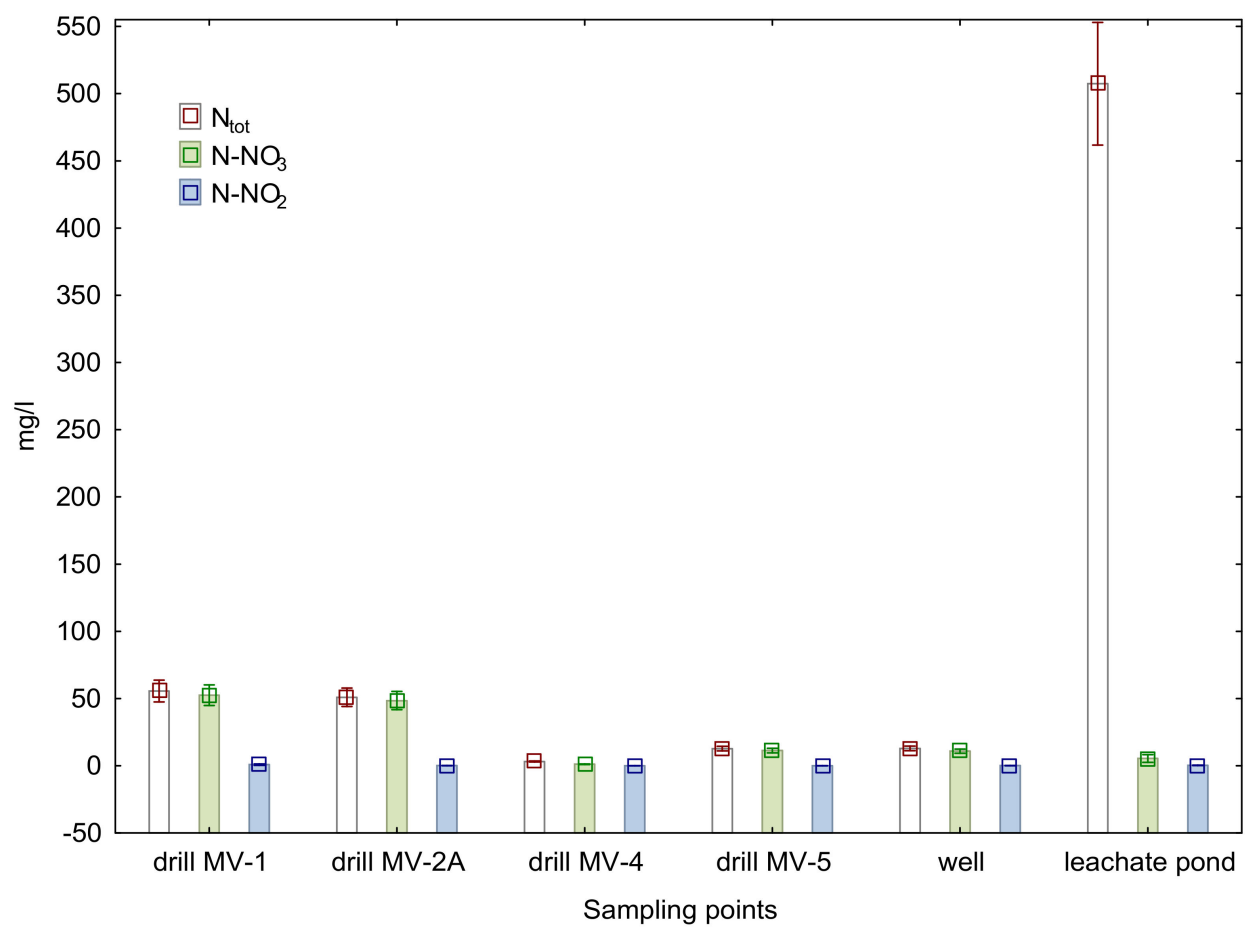

Figure A2. The concentration of N-compounds in the monitoring points for the period of five years (2008-2013). Average values $(n=12)$ of individual parameters \pm SD.

Table A3. Correlation matrix.

\begin{tabular}{cccccccccccccc}
\hline Variables & $\mathbf{p H}$ & $\mathbf{P}_{\text {tot }}$ & $\mathbf{N}_{\text {total }}$ & $\mathbf{C d}$ & $\mathbf{H g}$ & $\mathbf{Z n}$ & $\mathbf{C r}$ & $\mathbf{P b}$ & $\mathbf{N i}$ & $\mathbf{A s}$ & $\mathbf{C O D}$ & $\mathbf{P A H}$ & $\mathbf{A O X}$ \\
\hline $\mathrm{pH}$ & 1 & & & & & & & & & & & & \\
$\mathrm{P}_{\text {tot }}$ & 0.857 & 1 & & & & & & & & & & & \\
$\mathrm{~N}_{\text {total }}$ & 0.787 & 0.928 & 1 & & & & & & & & & & \\
$\mathrm{Cd}$ & 0.505 & 0.501 & 0.478 & 1 & & & & & & & & & \\
$\mathrm{Hg}$ & 0.364 & 0.113 & 0.129 & 0.164 & 1 & & & & & & & & \\
$\mathrm{Zn}$ & 0.679 & 0.667 & 0.650 & 0.312 & 0.578 & 1 & & & & & & & \\
$\mathrm{Cr}$ & 0.875 & 0.811 & 0.730 & 0.540 & 0.613 & 0.753 & 1 & & & & & & \\
$\mathrm{~Pb}$ & 0.542 & 0.584 & 0.693 & 0.571 & 0.152 & 0.257 & 0.536 & 1 & & & & & \\
$\mathrm{Ni}$ & 0.698 & 0.682 & 0.728 & 0.379 & 0.570 & 0.834 & 0.740 & 0.411 & 1 & & & & \\
$\mathrm{As}$ & 0.605 & 0.785 & 0.781 & 0.460 & -0.042 & 0.673 & 0.512 & 0.336 & 0.531 & 1 & & & \\
$\mathrm{COD}$ & 0.877 & 0.968 & 0.902 & 0.453 & 0.299 & 0.793 & 0.868 & 0.576 & 0.768 & 0.750 & 1 & & \\
$\mathrm{PAH}$ & 0.750 & 0.880 & 0.904 & 0.362 & 0.166 & 0.673 & 0.690 & 0.519 & 0.711 & 0.770 & 0.883 & 1 & \\
$\mathrm{AOX}$ & 0.871 & 0.963 & 0.938 & 0.508 & 0.275 & 0.725 & 0.866 & 0.645 & 0.785 & 0.727 & 0.965 & 0.849 & 1 \\
\hline
\end{tabular}

Note: The correlation coefficients are arranged in a correlation matrix. The correlation matrix was calculated using principle component analysis (PCA). The red highlighted correlation coefficient values show a significant dependence between particular parameters at a significance level $P<0.05$.

Table A4. The results of the factor analysis.

\begin{tabular}{cccc}
\hline & F1 & F2 & F3 \\
\hline $\mathrm{pH}$ & 0.894 & -0.046 & -0.067 \\
$\mathrm{P}_{\text {tot }}$ & 0.951 & 0.114 & 0.201 \\
$\mathrm{~N}_{\text {tot }}$ & 0.938 & 0.236 & 0.102 \\
$\mathrm{Cd}$ & 0.566 & 0.267 & -0.152 \\
$\mathrm{Hg}$ & 0.352 & -0.582 & -0.702 \\
$\mathrm{Zn}$ & 0.802 & -0.376 & -0.144 \\
$\mathrm{Cr}$ & 0.889 & -0.195 & -0.262 \\
$\mathrm{~Pb}$ & 0.643 & 0.376 & -0.128 \\
$\mathrm{Ni}$ & 0.824 & -0.291 & -0.209 \\
$\mathrm{As}$ & 0.774 & 0.114 & 0.383 \\
$\mathrm{COD}$ & 0.974 & -0.028 & 0.070 \\
$\mathrm{PAH}$ & 0.891 & 0.065 & 0.187 \\
$\mathrm{AOX}$ & 0.975 & 0.047 & 0.043 \\
\hline Variability & $61.6 \%$ & $10.5 \%$ & $8.7 \%$ \\
\hline
\end{tabular}

Note: The significant factor loading is red highlighted. The factors can be divided according Liu et al. [58] into strong $P>0.75$; medium $0.50-0.75$ and weak $0.50-0.30$. 


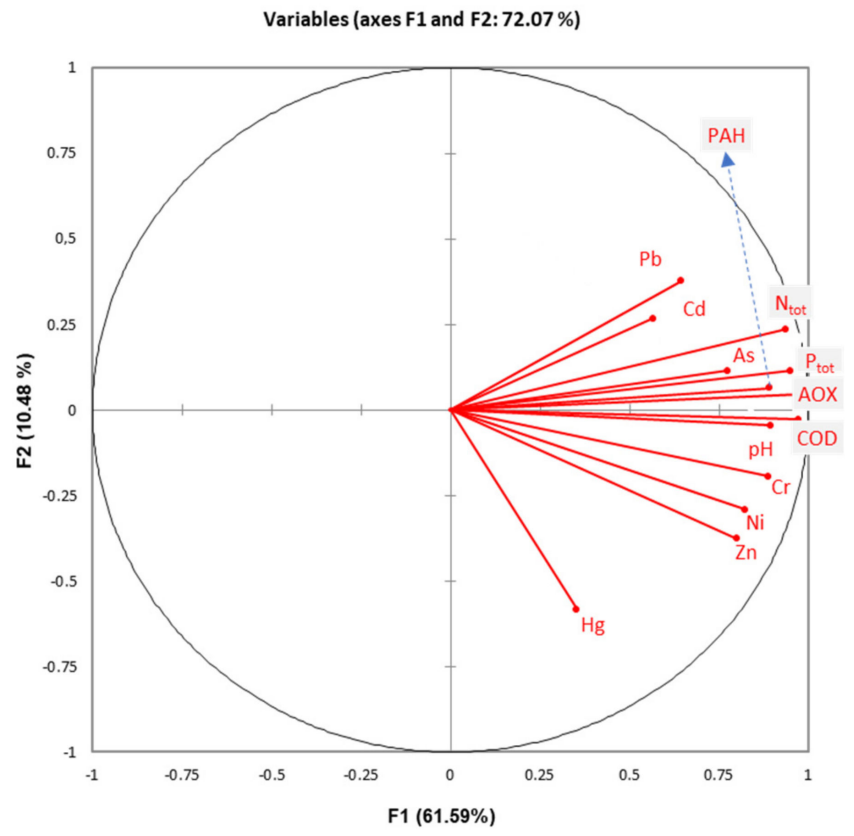

Figure A3. Plot of the PCA scores. Variable after varimax rotation.
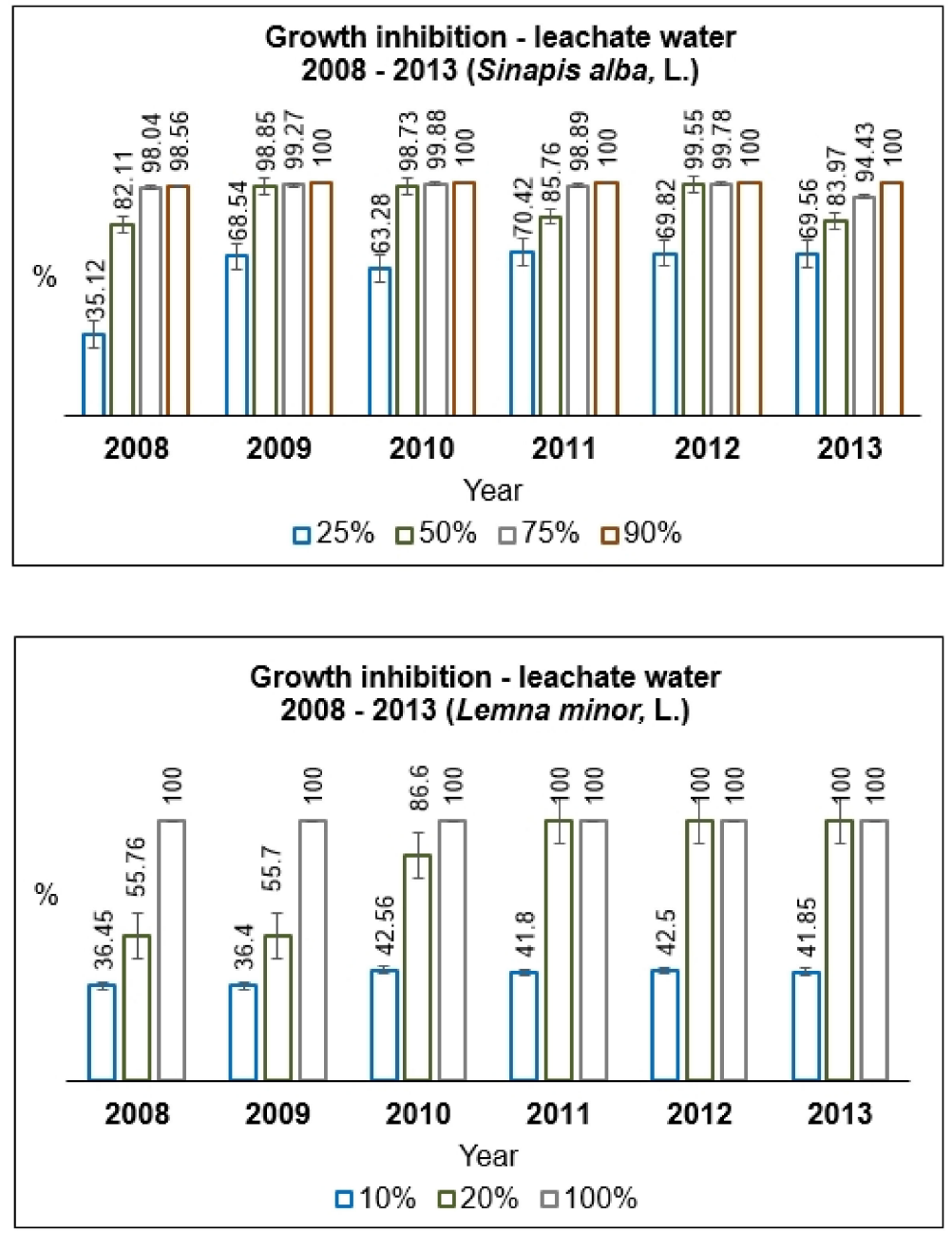

Figure A4. Growth inhibition: leachate water (2008-2013), Sinapis alba L. and Lemna minor L. 


\section{References}

1. Stańczyk-Mazanek, E.; Stępniak, L.; Kępa, U. Analysis of Migration of Polycyclic Aromatic Hydrocarbons from Sewage Sludge Used for Fertilization to Soils, Surface Waters, and Plants. Water 2019, 11, 1270. [CrossRef]

2. Chen, G.; Sun, Y.; Xu, Z.; Shan, X.; Chen, Z. Assessment of Shallow Groundwater Contamination Resulting from a Municipal Solid Waste Landfill-A Case Study in Lianyungang, China. Water 2019, 11, 2496. [CrossRef]

3. Krzykawska, K. A landfill peninsula as an experimental use space. A case study of Albany Bulb. Acta Sci. Pol. Archit. 2019, 18, 51-60. [CrossRef]

4. Singh, A. Managing the uncertainty problems of municipal solid waste disposal. J. Environ. Manag. 2019, 240, 259-265. [CrossRef] [PubMed]

5. Zornoza, R.; Moreno-Barriga, F.; Acosta, J.; Muñoz, M.; Faz, A. Stability, nutrient availability and hydrophobicity of biochars derived from manure, crop residues, and municipal solid waste for their use as soil amendments. Chemosphere 2016, 144, 122-130. [CrossRef] [PubMed]

6. Koda, E.; Osinski, P.; Kolanka, T. Flow numerical modeling for efficiency assessment of vertical barriers in landfill. In Coupled Phenomena in Environmental Geotechnics; CRC Press Ed.: London, UK, 2013; pp. $693-698$.

7. Shen, S.; Chen, Y.; Zhan, L.; Xie, H.; Bouazza, A.; He, F. Methane hotspot localization and visualization at a large-scale Xi'an landfill in China: Effective tool for landfill gas management. J. Environ. Manag. 2018, 225, 232-241. [CrossRef] [PubMed]

8. Shu, S.; Zhu, W.; Wang, S.; Ng, C.W.W.; Chen, Y.; Chiu, A.C.F. Leachate breakthrough mechanism and key pollutant indicator of municipal solid waste landfill barrier systems: Centrifuge and numerical modeling approach. Sci. Total Environ. 2018, 612, 1123-1131. [CrossRef] [PubMed]

9. Koda, E.; Tkaczyk, A.; Lech, M.; Osiński, P. Application of Electrical Resistivity Data Sets for the Evaluation of the Pollution Concentration Level within Landfill Subsoil. Appl. Sci. 2017, 7, 262. [CrossRef]

10. Jain, P.; Powell, J.T.; Smith, J.L.; Townsend, T.G.; Tolaymat, T. Life-cycle inventory and impact evaluation of mining municipal solid waste landfills. Environ. Sci. Technol. 2014, 48, 5, 2920-2927. [CrossRef]

11. Vaverková, M.D.; Adamcová, D. Heavy Metals Uptake by Select Plant Species in the Landfill Area of Štepánovice, Czech Republic. Pol. J. Environ. Stud. 2014, 23, 2265-2269. [CrossRef]

12. Samadder, S.R.; Prabhakar, R.; Khan, D.; Kishan, D.; Chauhan, M.S. Analysis of the contaminants released from municipal solid waste landfill site: A case study. Sci. Total Environ. 2017, 580, 593-601. [CrossRef] [PubMed]

13. Oliveiral, F.; Silvas, M.C.P.; Martinez, C.B.R. Assessment of domestic landfill leachate toxicity to the Asian Clam Corbicula fluminea via biomarkers. Ecotoxicol. Environ. Saf. 2014, 103, 17-23. [CrossRef] [PubMed]

14. Zloch, J.; Adamcova, D.; Vyhnanek, T.; Trojan, V.; Winkler, J.; Dordevic, B.; Bjelkova, M.; Radziemska, M.; Brtnicky, M.; Vaverkova, M.D. Assessment of the effect of landfill leachate irrigation of different doses on selected plants. In Proceedings of the International Ph.D. Students Conference MendelNet 2018, Brno, Czech Republic, 7-8 November 2018; Mendel University in Brno, Faculty of AgriSciences: Brno, Czech Republic, 2018; pp. 263-268.

15. Koda, E.; Zakowicz, S. Physical and hydraulics properties of the MSW for water balance of the landfill. In Proceedings of the 3rd International Congress on Environmental Geotechnics, Lisbon, Portugal, 7-11 September 1998; Balkema Ed. Volume 1, pp. 217-222.

16. Koda, E.; Osinski, P.; Sieczka, A.; Wychowaniak, D. Areal Distribution of Ammonium Contamination of Soil-Water Environment in the Vicinity of Old Municipal Landfill Site with Vertical Barrier. Water 2015, 7, 2656-2672. [CrossRef]

17. Ančić, M.; Huđek, A.; Rihtarić, I.; Cazar, M.; Bačun-Družina, V.; Kopjar, N.; Durgo, K. Physico chemical properties and toxicological effect of landfill groundwaters and leachates. Chemosphere 2020, 238, 124574. [CrossRef] [PubMed]

18. Zloch, J.; Vaverková, M.D.; Adamcová, D.; Radziemska, M.; Vyhnánek, T.; Trojan, V.; Đorđević, B.; Brtnický, M. Seasonal changes and toxic potency of landfill leachate for white mustard (Sinapis alba L.). Acta Univ. Agric. Silvic. Mendel. Brun. 2018, 66, 235-242. [CrossRef]

19. Kalčíková, G.; Pavko, J.B.A.; Gotvajn, A.Ž. Fungal and enzymatic treatment of mature municipal landfill leachate. Waste Manag. 2014, 34, 798-803. [CrossRef] 
20. Mackenzie, S.M.; Waite, S.; Metcalfe, D.J.; Joyce, C.B. Landfill Leachate Ecotoxicity Experiments using Lemna minor. Water Air Soil Pollut. 2003, 3, 171-179. [CrossRef]

21. Marchand, L.; Mench, M.; Marchand, C.; Le Coustumer, P.; Kolbas, A.; Maalouf, J.-P. Phytotoxicity testing of lysimeter leachates from aided phytostabilized $\mathrm{Cu}$-contaminated soils using duckweed (Lemna minor L.). Sci. Total Environ. 2011, 410-411, 146-153. [CrossRef]

22. Kim, H-Y. Analysis of variance (ANOVA) comparing means of more than two groups. Restor. Dent. Endod. 2014, 39, 74-77. [CrossRef]

23. Dillon, W.R.; Goldstein, M. Multivariate Analysis: Methods and Applications; Wiley: New York, NY, USA, 1984; p. 496.

24. Bilgin, A. An assessment of water quality in the Coruh Basin (Turkey) using multivariate statistical techniques. Environ. Monit. Assess. 2015, 187, 721. [CrossRef]

25. Wang, J.L.; Kang, S.Z.; Sun, J.S.; Chen, Z.F. Estimation of crop water requirement based on principal component analysis and geographically weighted regression. Chin. Sci. Bull. 2013, 58, 3371-3379. [CrossRef]

26. Kim, J.-O.; Muller, C.W. Factor Analysis: Statistical Methods and Practical Issues (Quantitative Applications in the Social Sciences); Sage: Newbury Park, CA, USA, 1989; p. 88.

27. Robinson, T. Removal of toxic metals during biological treatment of landfill leachates. Waste Manag. 2017, 63, 299-309. [CrossRef]

28. Bilardi, S.; Calabrò, P.S.; Greco, R.; Moraci, N. Selective removal of heavy metals from landfill leachate by reactive granular filters. Sci. Total Environ. 2018, 644, 335-341. [CrossRef] [PubMed]

29. Nair, A.T.; Senthilnathan, J.; Nagendra, S.M.S. Application of the phycoremediation process for tertiary treatment of landfill leachate and carbon dioxide mitigation. J. Water Process Eng. 2019, 28, 322-330. [CrossRef]

30. Olafisoye, O.B.; Adefioye, T.; Osibote, O.A. Heavy Metals Contamination of Water, Soil, and Plants around an Electronic Waste Dumpsite. Pol. J. Environ. Stud. 2013, 22, 1431-1439.

31. Chen, M.; Li, F.; Tao, M.; Hu, L.; Shi, Y.; Liu, Y. Distribution and ecological risks of heavy metals in river sediments and overlying water in typical mining areas of China. Mar. Pollut. Bull. 2019, 146, 893-899. [CrossRef]

32. WHO. Guidelines for Drinking-Water Quality; World Health Organization: Geneva, Switzerland, $2011 ;$ p. 564.

33. WHO. Guidelines for Drinking-Water Quality, Fourth edition incorporating the first addendum; World Health Organization: Geneva, Switzerland, 2017; p. 631.

34. Clara, M.; Windhofer, G.; Weilgony, P.; Gans, O.; Denner, M.; Chovanec, A.; Zessner, M. Identification of relevant micropollutants in Austrian municipal wastewater and their behaviour during wastewater treatment. Chemosphere 2012, 87, 1265-1272. [CrossRef]

35. Xie, Y.; Chen, L.; Liu, R. AOX contamination status and genotoxicity of AOX-bearing pharmaceutical wastewater. J. Environ. Sci. 2017, 52, 170-177. [CrossRef]

36. Lynch, J.P.; Brown, K.M. Topsoil foraging-An architectural adaptation of plants to low phosphorus availability. Plant Soil 2001, 237, 225-237. [CrossRef]

37. Bhutiani, R.; Kulkarni, D.B.; Khanna, D.R.; Gautam, A. Water Quality, Pollution Source Apportionment and Health Risk Assessment of Heavy Metals in Groundwater of an Industrial Area in North India. In Exposure and Health; Meharg, A., Ed.; Springer Nature: Basel, Switzerland, 2016; Volume 8, pp. 3-18.

38. Abboud, E.; Favaretto, N.; Motta, A.C.V.; Barth, G.; Goularte, G.D. Phosphorus mobility and degree of saturation in oxisol under no-tillage after long-term dairy liquid manure application. Soil Tillage Res. 2018, 177, 45-53. [CrossRef]

39. Chapman, D. 1996 Water Quality Assessments. In A Guide to the Use of Biota, Sediments and Water in Environmental Monitoring, 2nd ed.; Chapman, D., Ed.; Chapman \& Hall: London, UK, 1996.

40. Xie, Y.; Chen, L.; Liu, R. Oxidation of AOX and organic compounds in pharmaceutical wastewater in RSM-optimized-Fenton system. Chemosphere 2016, 155, 217-224. [CrossRef] [PubMed]

41. Farooqi, I.H.; Basheer, F. Treatment of Adsorbable Organic Halide (AOX) from pulp and paper industry wastewater using aerobic granules in pilot scale SBR. J. Water Process Eng. 2017, 19, 60-66. [CrossRef]

42. Hoekstra, E.J.; Verhagen, F.J.M.; Field, J.A.; De Leer, E.W.B.D.; Brinkman, U.A.T. Natural production of chloroform by fungi. Phytochemistry 1998, 49, 91-97. [CrossRef]

43. Hindersmann, B.; Achten, C. Urban soils impacted by tailings from coal mining: PAH source identification by 59 PAHs, BPCA and alkylated PAHs. Environ. Pollut. 2018, 242, 1217-1225. [CrossRef] [PubMed] 
44. Dabrowska, D.; Witkowski, A.; Sołtysiak, M. Representativeness of the groundwater monitoring results in the context of its methodology: Case study of a municipal landfill complex in Poland. Environ. Earth Sci. 2018, 77, 266. [CrossRef]

45. Tchounwou, P.B.; Yedjou, C.G.; Patlolla, A.K.; Sutton, D.J. Heavy metal toxicity and the environment. Exp. Suppl. 2012, 101, 133-164. [PubMed]

46. Przydatek, G. Multi-indicator analysis of the influence of old municipal landfill sites on the aquatic environment: Case study. Environ. Monit. Assess. 2019, 191, 773. [CrossRef]

47. Rutkowska, G.; Fronczyk, J.; Wichowski, P. Research on the Possibility of Using Fly Ashes from Combustion of Municipal Sewage Sludge on Properties of Ordinary Concretes. Annu. Environ. Protect. 2018, 20, 1113-1128.

48. Wang, P.; Sun, Z.; Hu, Y.; Hefa, C. Leaching of heavy metals from abandoned mine tailings brought by precipitation and the associated environmental impact. Sci. Total Environ. 2019, 695. [CrossRef]

49. Hair, J.F.; Black, W.C.; Babin, B.J.; Anderson, R.E. Multivariate Data Analysis, 7th ed.; Pearson Education Limited: New York, NY, USA, 2014; p. 739.

50. Cheng, C.Y.; Chu, L.M. Phytotoxicity data safeguard the performance of the recipient plants in leachate irrigation. Environ. Pollut. 2007, 145, 195-202. [CrossRef]

51. Guerrero-Rodríguez, D.; Sánchez-Yáñez, J.M.; Buenrostro-Delgado, O. Phytotoxic Effect of Landfill Leachate with Different Pollution Indexes on Common Bean. Water Air Soil Pollut. 2014, 2002, 225. [CrossRef]

52. Santos, C.A.; Panchoni, L.; Bini, D.; Kuwano, B.H.; Carmo, K.B.; Silva, S.M. Land application of municipal landfill leachate: Fate of ions and ammonia volatilization. J. Environ. Qual. 2013, 42, 523-531. [CrossRef]

53. Kaszubkiewicz, J.; Gałka, B.; Kawałko, D. Impact of legal and illegal waste dumps on the surrounding soils in the Jelenia Góra and Wrocław districts. Soil Sci. Annu. 2011, 62, 179-188.

54. Jahan, E.; Nessa, A.; Hossain, M.F.; Parveen, Z. Characteristics of Municipal Landfill Leachate and its Impact on Surrounding Agricultural Land. Bangladesh J. Sci. Res. 2016, 242, 1217-1225. [CrossRef]

55. Torma, S.; Vilček, J.; Lošák, T.; Kužel, S.; Martensson, A. Residual plant nutrients in crop residues-An important resource. Acta Agric. Scand. 2018, 68, 358-366. [CrossRef]

56. Losak, T.; Hlusek, J.; Zatloukalova, A.; Musilova, A.; Vitezova, M.; Skarpa, P.; Zlamalova, T.; Fryc, J.; Vitez, T.; Marecek, J.; et al. Digestate from biogas plants is an attractive alternative to mineral fertilisation of Kohlrabi. J. Sustain. Dev. Energy Water Environ. Syst. 2014, 2, 309-318. [CrossRef]

57. Liu, C.W.; Lin, K.H.; Kuo, Y.M. Application of factor analysis in the assessment of groundwater quality in a blackfoot disease area in Taiwan. Sci. Total Environ. 2003, 313, 77-89. [CrossRef]

58. Hlavinka, P.; Trnka, M.; Kersebaum, K.C.; Čermák, P.; Pohanková, E.; Orság, M.; Pokorný, E.; Fischer, M.; Brtnický, M.; Žalud, Z. Modelling of yields and soil nitrogen dynamics for crop rotations by HERMES under different climate and soil conditions in the Czech Republic. J. Agric. Sci. 2013, 152, 188-204. [CrossRef] 